\title{
POTENSI EKSTRAK DAUN NANGKA (Artocarpus heterophyllus Lamk) SEBAGAI BIOLARVASIDA NYAMUK Culex sp
}

\author{
Asro Abdi Firdaus,Setiawan,Ferry Kriswandana
}

\begin{abstract}
Mosquitoes are type of insect that acts as a disease vector. One of them is Culex $s p$ mosquitos which their existence is many around us. In Indonesia there are still a lot of disease cases that caused by Culex $s p$ mosquitos, one of them is filariasis disease. The efforts to control the current population of Culex $s p$ mosquitoes mostly use chemical insecticides. The control becomes difficult because of the resistance to chemical insecticides and adversely affects the environment.

This study aims to determine the potential of jackfruit leaf extract as biolarvasida against Culex $s p$. The type of this study was post test only controlled group design, using 625 larvae Culex $s p$ instar III, divided into 5 groups (negative control group, $0.25 \%$ extract, $0.50 \%$ extract, $0.75 \%$ extract, extract and $1 \%$ extract). Observation was performed 24 hours after the treatment and counted the number of larvae death.

The data were analyzed by Kruskal Wallis test followed by Post Hoc MannWhitney $\mathrm{U}$ test to determine the killing power of leafy leaf extract using Probit analysis. The results of data analysis in this study were the death rate percentage of larvae after 24 hours treatment was $0 \%$ in control, $44 \%$ in $0.25 \%$ extract, $52 \%$ in $0.50 \%$ extract, $60 \%$ in $0.75 \%$ extract, while in the extract group of $1 \%$, the number of larval deaths was $72 \%$. It obtained results with significant differencein some treatment groups that were concentrations of $0.25 \%-1 \%$. Probit analysis showed that LC50 was at $0.382 \%$ concentration.

From results of the studyit can be concluded that jackfruit leaf extract (Artocarpus heterophyllus Lamk) was potential as Culex $s p$ mosquito biolarvacide. So it is necessary to conduct further research on the effects of compounds that contained in other plant parts such as flowers, stems and roots which will be expected to have a function asbiolarvasida.
\end{abstract}

Keywords: Leaf Jackfruit, Biolarvasida, Mosquito Culex sp

\section{PENDAHULUAN}

Nyamuk merupakan salah satu jenis serangga yang dapat merugikan manusia karena peranannya sebagai vektor penyakit. Beberapa jenis penyakit seperti West Nile Virus, Japanese enchepalitis, St Louis encephalitis dan Filariasis dapat ditularkan melalui nyamuk Culex sp (Rahmawati,2013:207). Nyamuk genus ini merupakan nyamuk yang banyak terdapat disekitar kita dan dapat mengganggu kehidupan manusia karena gigitannya. Berdasarkan data Kementerian Kesehatan RI, di Indonesia hingga tahun 2016 telah ditemukan lebih dari 13.032 penderia filariasis kronis atau penyakit kaki gajah. Jumlah ini tersebar di 429 kabupaten/kota di seluruh Indonesia (Sindonews, 27 September 2016).
Jumlah penderita penyakit filariasis ini dari tahun ke tahun masih terdapat kasus. Menurut Data Dinas Kesehatan Provinsi Jawa Timur total kasus filariasis dari 38 kabupaten/kota selama 3 tahun terakhir sebanyak 381 penderita kronis filariasis (Dinas Kesehatan Provinsi Jawa Timur).

Masih terdapatnya kasus filariasis membutuhkan pengendalian yang tepat untuk menurunkan kasus tersebut. Upaya pengendalian untuk mencegah penyakit yang ditularkan oleh vektor dimulai dari tahap larva. Pengendalian larva nyamuk Culex $s p$ yang selama ini sering dilakukan adalah pengendalian secara biologi dengan menggunakan organisme, pengendalian mekanik seperti modifikasi lingkungan dan pengendalian kimiawi dengan menggunakan zat kimia. 
Pengendalian secara kimia dapat menekan populasi vektor lebih cepat dibandingkan biologi dan mekanik. Menurut World Health Organization,2002:6 tentang Defining The Roles of Vector Control And Xenomonitoring In The Global Programme To Eliminate Lymphatic Filariasis. Pengendalian kimia untuk larva nyamuk Culex $s p$ yaitu dengan cara menuangkan minyak di parit dengan MLO (Mosquito Larvicidal Oils) yang secara khusus berasal dari hasil penyulingan minyak bumi dan telah digunakan selama bertahun-tahun di (AS) Amerika Serikat untuk membunuh kutu daun pada tanaman, dan untuk mengendalikan nyamuk. Minyak akan mengemulsi dengan deterjen yang berada di perairan tercemar dimana tempat habitat larva nyamuk Culex $s p$.

Jika di tuang ke dalam parit, maka minyak akanmembentuk lapisan pada permukaan air dan akan membunuh larva, karena adanya lapisan minyak yang menutupi permukaan air sehingga dapat menghalangi larva dalam bernapas dan akhirnya mati. Minyak akan mengemulsi dengan deterjen yang berada di perairan tercemar dimana tempat habitat larva nyamuk Culex $s p$. Namun metode ini kurang cocok karena dapat beracun bagi ikan dan organisme air lainnya serta sifat minyak yang menutupi seluruh permukaan air dan masa jenis minyak lebih berat serta cenderung menyumbat lubang parit dan mencemari lingkungan (US EPA,2000:6).

Pengendalian larva secara kimia selanjutnya yaitu dengan metode (EPS) (Expanded Polystyrene) dengan pemberian manik-manik polystyrene yang membentuk lapisan mengambang pada habitat larva nyamuk Culex $s p$. Metode ini berfungsi sebagai penghalang fisik untuk nyamuk dewasa Culex $s p$ bertelur dan juga membunuh larva maupun pupa. Namun metode ini hanya dapat digunakan dalam habitat di mana air tergenang terkurung dalam dinding (WHO,2002:7). Selain itu pengendalian larva secara kimia dapat dilakukan dengan pemberian Methoprene, dimana fungsi senyawa tersebut untuk mengatur pertumbuhan serangga dan mencegah pematangan normal larva serangga. Altosid adalah nama produk methoprene digunakan dalam pengendalian nyamuk dan diterapkan sebagai briket (mirip dengan briket arang), pelet, butiran pasir, dan cairan yang mana dapat diaplikasikan pada parit, kolam, rawarawa atau daerah banjir yang tidak menjadi sumber air minum. Kekurangan Methoprene yaitu sangat beracun untuk beberapa spesies air tawar, muara, dan invertebrata laut jika disalahgunakan (US EPA, 2000:3-4).

Namun, pengendalian dengan cara ini apabila dilakukan secara terus menerus kurang efektif karena dapat menyebabkan resistensi bagi larva, kematian bagi hewan predator larva dan pencemaran lingkungan. Sehubungan mengenai kerugian yang dapat ditimbulkan oleh pengendalian kimia terebut maka perlu dilakukan suatu usaha untuk memutus mata rantai penularan penyakit dengan menggunakan larvasida yang tidak mencemari lingkungan dan relatif aman bagi manusia, yaitu dengan memanfaatkan tumbuh-tumbuhan yang berasal dari alam.

$\mathrm{Di}$ Indonesaia penanggulangan vektor penyakit yang sering diaplikasikan yaitu menggunakan larvasida pada larva nyamuk Aedes aegypti dan jarang pengaplikasian pada larva nyamuk Culex $s p$ sehingga disini peneliti berkeinginan membuat biolarvasida untuk nyamuk Culex $s p$. Larvasida berfungsi sebagai pembunuh larva serangga serta dapat mengurangi populasi nyamuk dewasa di suatu daerah.

Larvasida yang umumnya dikenal dengan biolarvasida digunakan sebagai alternatif untuk mengurangi penggunaan zat kimiawi pada larva (Mittal.P.K,2003:20). Biolarvasida ini sangat efektif terhadap larva nyamuk pada dosis yang sangat rendah dan benar-benar aman untuk organisme nontarget lainnya, lingkungan, manusia dan kehidupan liar, dan cocok untuk digunakan masyarakat. (Mittal.P.K,2003: $20-21$ ).

Indonesia dikenal dengan negara yang memiliki kekayaan keanekaragaman hayati (Mega-biodiversity) terbesar kedua 
di dunia setelah Brazil, dan termasuk memiliki sejumlah tanaman yang dapat digunakan sebagai bahan dasar insektisida, baik yang dapat langsung digunakan atau dengan ekstraksi sederhana dengan air, ekstraksi dengan pelarut organik lainnya ataupun dengan cara penyulingan, tergantung kepada tujuan dari formula yang akan dibuat (Puslitbang Perkebunan,2012:1).

Salah satu tumbuhan yang diduga dapat membunuh larva nyamuk adalah daun nangka (Artocarpus heterophyllus Lamk). Daun nangka dipilih karena mudah diperoleh, keberadaannya banyak sekali disekitar kita dan masih belum pernah dilakukan penelitian biolarvasida menggunakan daun nangka.

Menurut Hutapea,1993:59-60 dalam buku Inventaris Tanaman Obat Indonesia II tanaman nangka daunnya mengandung saponin,flavonoid, dan tanin. Dan Asmaliyah,2010:37 dalam buku Pengenalan Tumbuhan Penghasil Pestisida Nabati Dan Pemanfaatannya Secara Tradisional. Bahwa tumbuhan nangka mengandung senyawa kimia pada daun mengandung saponin, flavonoid, dan tanin, buah muda mengandung saponin dan polifenol. Berdasarkan uji pendahuluan yang dilakukan pada daun nangka didapatkan kandungan tanin sebesar $3,08 \%$,flavonoid sebesar 0,92\%, dan saponin sebesar $1,36 \%$.

Menurut Cania Eka,2013 dalam penelitiannya yang berjudul "Uji Efektivitas Larvasida Ekstrak Daun Legundi (Vitex Trifolia)" ekstrak daun legundi mengandung saponin, flavonoid, alkaloid dan miyak atsiri, dengan berbagai konsentrasi ekstrak yang dibutuhkan $0.25 \%, 0,50 \%, 0.75 \%$ dan $1 \%$. saponin, flavonoid, dan alkaloid, dapat berperan sebagai racun perut serta racun pernapasan sehingga mengakibatkan kematian pada larva.

Konsentrasi ekstrak daun legundi yang optimal untuk mengendalikan larva Aedes aegypti yaitu sebesar 1,0\% menyebabkan kematian larva sebesar 95\% dalam 72 jam perlakuan. Hasil tersebut menunjukkan bahwa ekstrak daun legundi mempunyai efektivitas larvasida terhadap larva Aedes aegypti.
Persamaan penelitian ini dengan peneliti terdahulu adalah konsentrasi ekstrak yang digunakan yaitu $0.25 \%, 0,50 \%$, $0.75 \%$ dan $1 \%$ dan metode ekstraksi yang digunakan yaitu dengan metode miserasi. Adapun letak perbedaan penelitian ini dengan peneliti terdahulu adalah bahan yang digunakan yaitu daun nangka, senyawa yang dipilih adalah saponin, flavonoid, tannin, Larva uji yang digunakan adalah genus Culex $s p$ dan waktu pengamatan kematian larva yaitu selama 24 jam perlakuan.

Pada beberapa penelitian yang telah dilakukan, saponin memiliki cara kerja sebagai racun perut dan menghambat kerja enzim kolinesterase pada larva dan flavonoid berperan sebagai racun pernapasan sehingga menyebabkan kematian larva (Cania,2013:53). Sedangkan tanin dapat mengurangi asupan makan dan memiliki efek pada proses pertumbuhan larva sehingga larva tidak dapat berkembang dan akhirnya mati (SinghV.K. et.al.2006:342).

\section{METODE PENELITIAN}

Jenis penelitian ini adalah penelitian eksperimen dengan desain post test only control group design. Obyek Penelitian ini adalah ekstrak daun nangka (Artocarpus heterophyllus Lamk) dengan konsentrasi sebesar $(0,25 \%, 0,50 \%, 0,75 \%, 1 \%)$ dan 1 kontrol (0\%).

Dan larva nyamuk Culex $s p$ instar III yang di peroleh dari Dinas Kesehatan Provinsi Jawa Timur. Jumlah larva yang digunakan dalam penelitian ini adalah 25 ekor larva setiap unit perlakuan,dengan pertimbangan untuk eksperimen larva 20-25 ekor (WHO,2005:10), dengan media yang digunakan adalah air sumur sebanyak $200 \mathrm{ml}$.

\section{HASIL DAN PEMBAHASAN Jumlah Kematian Larva Nyamuk Culex sp.}

Pada penelitian ini, kematian larva nyamuk Culex sp diamati selama24 jam perlakuan. Kematian larva nyamuk Culex $s p$ ditandai dengan larva yang tidak bergerak, tidak memberikan respon ketika disentuh dengan lidi khususnya pada bagian sifon atau servikal, tubuh tenggelam, tubuh membengkok, 
memanjang, berwarna pucat bahkan ada (Rahmawati,2013:209).

yang terlihat tubuhnya hancur

Tabel 1

Jumlah Kematian Larva Nyamuk Culex sp Dengan Pemberian Ekstrak Daun Nangka (Artocarpus heterophyllus Lamk) Selama 24 Jam

\begin{tabular}{|c|c|c|c|c|c|c|c|}
\hline \multirow{2}{*}{ Konsentrasi } & \multicolumn{5}{|c|}{ Replikasi } & \multirow{2}{*}{$\begin{array}{c}\text { Rata - } \\
\text { rata }\end{array}$} & \multirow[t]{2}{*}{ Persentase } \\
\hline & 1 & 2 & 3 & 4 & 5 & & \\
\hline $0 \%$ & 0 & 0 & 0 & 0 & 0 & 0 & $0 \%$ \\
\hline $0,25 \%$ & 10 & 11 & 9 & 11 & 12 & 11 & $44 \%$ \\
\hline $0,50 \%$ & 14 & 13 & 12 & 12 & 13 & 13 & $52 \%$ \\
\hline $0,75 \%$ & 15 & 16 & 14 & 17 & 15 & 15 & $60 \%$ \\
\hline $1 \%$ & 17 & 18 & 19 & 17 & 18 & 18 & $72 \%$ \\
\hline
\end{tabular}

Berdasarkan hasil penelitian yang telah

Hal ini membuktikan bahwa adanya efek dilakukan dengan menggunakan ekstrak larvasida pada pemberian ekstrak daun daun nangka (Artocarpus heterophyllus nangka (Artocarpus heterophyllus Lamk) Lamk) pada konsentrasi $0 \%, 0.25 \%$, pada larva uji. $0.50 \%, 0.75 \%$, dan $1 \%$ dengan perlakuan Nilai LC 50 Ekstrak Daun Nangka selama 24 jam didapatkan hasil rata-rata (Artocarpus heterophyllus Lamk) persentase kematian larva berturut-turut Terhadap Kematian Larva Nyamuk sebesar $0 \%, 44 \%, 52 \%, 60 \%$ dan $72 \%$.

Culex sp.

Kematian larva Culex $s p$ terdapat pada Nilai $\mathrm{LC}_{50}$ adalah konsentrasi dari suatu semua kelompok perlakuan, sedangkan bahan yang menyebabkan $50 \%$ larva uji pada kelompok konsentrasi $0 \%$ (kontrol) mengalami kematian.

tidak terdapat kematian larva Culex $s p$.

Tabel 2

Hasil Nilai LC 50 Ekstrak Daun Nangka (Artocarpus heterophyllus Lamk) Terhadap Kematian Larva Culex sp

Rata - Rata Maksimum Minimum
0,382
0,657
0,000

Berdasakan hasil pengolahan data nilai $\mathrm{LC}_{50}$ uji toksisitas ekstrak daun nangka (Artocarpus heterophyllus Lamk) terhadap larva nyamuk Culex $s p$, di dapatkan hasil bahwa konsentrasi yang mampu membunuh $50 \%$ dari larva uji nyamuk Culex sp sebesar 0,382\% selama 24 jam perlakuan. 
Hal ini sesuai dengan WHO dalam Terhadap Kematian Larva Nyamuk buku "Guidelines For Laboratory And Field Culex sp

Testing Of Mosquito Larvacides": 2005 Untuk menganilisis perbedaan dengan presentase maksimal penelitian konsentrasi ekstrakdaun nangka larvasida yang digunakan sebesar 1\%, (Artocarpus heterophyllus Lamk) terhadap yang berarti hasil uji $\mathrm{LC}_{50}$ sebesar $0,382 \%$ kematian larva Culex $s p$ dilakukan (di bawah standar WHO) efektif untuk pengujian statistik menggunakan uji beda membunuh 50\% larva uji. Kruskal Waills dan Untuk melihat adanya

dua kelompok yang memilik perbedaan
Analisis
Perbedaan
Konsentrasi
Ekstrak
Daun Nangka
(Artocarpus
heterophyllus
Lamk)
Hoc Mann Whitney $U$.

Tabel 3

Hasil Uji Beda (Kruskal Waills) BerbagaiEkstrak Daun Nangka(Artocarpus heterophyllus Lamk) Terhadap Kematian Larva Culex sp

\begin{tabular}{|c|c|c|c|c|}
\hline \multirow{7}{*}{$\begin{array}{c}\text { Kematian } \\
\text { Larva }\end{array}$} & Perlakuan & $\mathbf{N}$ & $\begin{array}{l}\text { Mean } \\
\text { Rank }\end{array}$ & $\mathbf{P}$ \\
\hline & Konsentrasi $0 \%$ & 24 & 154.50 & \multirow{6}{*}{0,000} \\
\hline & Konsentrasi $0,25 \%$ & 120 & 238.23 & \\
\hline & Konsentrasi $0,50 \%$ & 120 & 250.01 & \\
\hline & Konsentrasi $0,75 \%$ & 120 & 265.30 & \\
\hline & Konsentrasi $1 \%$ & 120 & 276.06 & \\
\hline & Total & 504 & & \\
\hline
\end{tabular}

Hasil ini menunjukkan bahwa nilai $\mathrm{p}=\mathrm{Hal}$ ini menunjukkan bahwa setiap $0,000<a(0,05)$ yang berarti bahwa pemberian konsentrasi ekstrak daun terdapat perbedaan yang signifikan pada 5 nangka (Artocarpus heterophyllus Lamk) konsentrasi ekstrak daun nangka dengan konsentrasi yang berbeda pada (Artocarpus heterophyllus Lamk) sebagai larva Culex sp mempengaruhi jumlah biolarvasida terhadap kematian larva kematian larva. Terjadinya kematian larva nyamuk Culex $s p$ selama 24 jam Culex $s p$ pada berbagai konsentrasi perlakuan. Untuk melihat adanya dua disebabkan oleh banyaknya senyawa aktif kelompok yangmemilik perbedaan yang yang kontak langsung dengan larva Culex signifikan, maka dilakukan uji Pos Hoc sp pada media air.

Mann Whitney $U$.

Semakin tinggi konsentrasi yang diberikan

Pada uji ini menunjukkan bahwa terdapat maka senyawa aktif yang diterima larva perbedaan yang signifikan pada kelompok Culex $s p$ semakin banyak. hal ini perlakuan konsentrasi yang berbeda yaitu menunjukkan bahwa senyawa kimia yang pada kelompok perlakuan konsentrasi paling berpengaruh dalam menyebabkan $0,25 \%$ dengan kelompok perlakuan kematian larva adalah saponin dan tanin, konsentrasi $1 \%$ dengan nilai $\mathrm{p}=0,000>$ tetapi flavonoid juga berperan dalam a $(0,05)$ dan hasil mean rank paling menyebabkan kematian larva.

signifikan 129,73 . 
Efek larvasida senyawa flavonoid, saponin Hasil pengukuran faktor lingkungan fisik dan tanin yaitu sebagai racun pernafasan, dapat dikatakan bahwa $\mathrm{pH}$, suhu media racun perut dan penghambat asupan air, suhu ruangan penelitian dan makan serangga. Senyawa-senyawa kelembapan ruangan penelitian bukan tersebut larut di dalam air dan akhirnya merupakan faktor yang dapat masuk kedalam sistem pernafasan dan mempengaruhi tingkat kematian larva sistem pencernaan serta mengakibatkan nyamuk Culex $s p$. Sehingga dapat gangguan pernafasan dan pencernaan dikatakan bahwa kematian larva Culex $s p$ larva sehingga larva gagal tumbuh dan disebabkan oleh pemberian berbagai akhirnya mati (Suyanto,2009 dalam konsentrasi ekstrak daun nangka Haditomo,2010:7-8). (Artocarpus heterophyllus Lamk).

Tabel 4

Hasil Uji Post Hoc Mann Whitney UTerhadap Kematian Larva Culex sp

\begin{tabular}{|c|c|c|c|}
\hline & & Mean & \multirow{3}{*}{$\mathbf{P}$} \\
\hline \multirow{2}{*}{ No. } & Konsentrasi & \multirow[b]{2}{*}{ Rank } & \\
\hline & & & \\
\hline 1. & $0 \%-0,25 \%$ & $51,00-76,80$ & 0,001 \\
\hline 2. & $0 \%-0,50 \%$ & $49,50-77,10$ & 0,000 \\
\hline 3. & $0 \%-0,75 \%$ & $47,00-77,60$ & 0,000 \\
\hline 4. & $0 \%-1 \%$ & $44,50-78,10$ & 0,000 \\
\hline \multirow{3}{*}{5.} & $0,25 \%-$ & $117,69-123,31$ & \multirow{3}{*}{0,464} \\
\hline & \multirow[b]{2}{*}{$0,50 \%$} & & \\
\hline & & & \\
\hline \multirow{3}{*}{6.} & $0,25 \%-$ & $113,97-127,03$ & \multirow{3}{*}{0,094} \\
\hline & \multirow[b]{2}{*}{$0,75 \%$} & & \\
\hline & & & \\
\hline 7. & $0,25 \%-1 \%$ & $111,28-129,73$ & 0,020 \\
\hline \multirow{3}{*}{8.} & $0,50 \%-$ & $116,84-124,16$ & \multirow{3}{*}{0,353} \\
\hline & \multirow[b]{2}{*}{$0,75 \%$} & & \\
\hline & & & \\
\hline 9. & $0,50 \%-1 \%$ & $114,26-126,74$ & 0,117 \\
\hline 10. & $0,75 \%-1 \%$ & $118,01-122,99$ & 0,536 \\
\hline
\end{tabular}

KESIMPULAN

konsentrasi $0,25 \%$ yaitu 11 ekor (44\%) Persentase rata-rata jumlah kematian larva dan kematian tertinggi terdapat pada Culex sp pada konsentrasi $0,25 \%, 0.50 \%$, konsentrasi $1 \%$ yaitu 18 ekor (72\%). $0.75 \%$, dan $1 \%$ selama 24 jam adalah $44 \%$, Sedangkan pada kontrol tidak menunjukkan $52 \%, 60 \%$, dan $72 \%$. Dengan rata - rata adanya kematian larva Culex sp. kematian terendah terdapat pada 
Nilai $\mathrm{LC}_{50}$ konsentrasi ekstrak daun nangka (Artocarpus heterophyllus Lamk) yang dapat membunuh $50 \%$ populasi larva nyamuk Culex sp selama 24 jam adalah sebesar Hutapea, J.R. (1993). Inventaris Tanaman $0,382 \%$.

Terdapat perbedaan kematian larva nyamuk Culex $s p$ terhadap berbagai konsentrasi ekstrak daun nangka Kementerian Pertanian BP dan (Artocarpus heterophyllus Lamk) sebagai biolarvasida.

\section{SARAN}

Bagi Instansi terkait (Dinas Kesehatan) sebagai referensi untuk mengurangi penggunakan insektisida kimia dalam Rahmawati,dkk.2013.Pemanfaata n Biji pengendalian populasi larva nyamuk Culex $s p$. Bagi peneliti lain perlu dikembangkan penelitian dengan uji coba pada spesies U.S. larva nyamuk lain. Perlu dilakukan penelitian lebih lanjut mengenai efek senyawa yang terkandung pada bagian tumbuhan lainnya seperti bunga, batang dan akar yang nantinya diharapkan dapat Mittal, berfungsi sebagai biolarvasida.

Penelitian selanjutnya dapat dilakukan dengan menggunakan media air pada habitat asli larva nyamuk nyamuk Culex $s p$ pada air kotor seperti pada saluran pembuangan limbah rumah tangga dan air parit.

\section{DAFTAR PUSTAKA}

Asmaliyah

Tumbuhan Penghasil Pestisida Nabati Singh V.K. et.al.2006.Recent Progress In

Dan Pemanfaatannya Secara

Tradisional. Palembang: Kementerian

Kehutanan Badan Penelitian Dan

Pengembangan Kehutanan

Pusat Penelitian Dan Pengembangan Produktivitas Hutan. Hal : 37. ISBN : 978-602-98588-0-8.

Cania,Eka.B.2013. Uji Efektivitas Larvasida Ekstrak Daun Legundi (Vitex Trifolia) Terhadap Larva Aedes
Aegypti.Lampung:Medical Journal Of Lampung University Volume 2 No 4 Februari 2013. ISSN 23373776. Hal:53:58 Obat Indonesia, edisi II. Depkes RI Badan Penelitian dan Pengembangan Kesehatan : Jakarta.Hal:59-60 P2.2012. Pestisida Nabati. Bogor: Pusat Penelitian dan Pengembangan Perkebunan.Hal:1.

Rafika,Diana.2016."Penderita Kaki Gajah di Indonesia Mencapai 13.032".Sindo News. 27 September 2016. Mimba (Azadirachta indica) Sebagai Larvasida Nyamuk Culex sp.Surabaya EPA.2002.For Your Information larvicides for Mosquito Control Prevention,Pesticides, and Toxic Substances. U.S.Environmental Protection Agency.Hal: 1-6.

P.K.2003. Biolarvicides in Vector Control : Challenges

ingh V.K. et.al.2006.Recent Progress In Medicinal Plants, Volume 15: Natural Products 1.New Delhi: ISBN 10:

Hadiutomo,Indriantoro.2010. Efek Larvasida Ekstrak Daun Cengkeh (Syzygium Aromaticum L.Terhadap Aedes Aegypti L.Surakarta: Fakultas Kedokteran Universitas Sebelas Maret.Hal:8:33 Medicinal Plants, Volume 15: Natural Product 1.New Delhi: ISBN 10:0976184974. Hal:342.

Hadiutomo,Indriantoro.2010. Efek Larvasida Ekstrak Daun Cengkeh (Syzygium Aromaticum L.) Terhadap Aedes Aegypti L.Surakarta: Fakultas Kedokteran Universitas Sebelas Maret.Hal:8:33 